\title{
Copper and Gold Nanoparticles Increase Nutrient Excretion Rates of Primary Consumers
}

\author{
Brittany G. Perrotta,* Marie Simonin, Jeffrey A. Back, Steven M. Anderson, Astrid Avellan, \\ Christina M. Bergemann, Benjamin T. Castellon, Benjamin P. Colman, Gregory V. Lowry, \\ Cole W. Matson, Emily S. Bernhardt, and Ryan S. King*
}

Cite This: https://dx.doi.org/10.1021/acs.est.0c02197

Read Online

\begin{abstract}
ACCESS
W Metrics \& More

Article Recommendations

Supporting Information

ABSTRACT: Freshwater ecosystems are exposed to engineered nanoparticles through municipal and industrial wastewater-effluent discharges and agricultural nonpoint source runoff. Because previous work has shown that engineered nanoparticles from these sources can accumulate in freshwater algal assemblages, we hypothesized that nanoparticles may affect the biology of primary consumers by altering the processing of two critical nutrients associated with growth and survivorship, nitrogen and phosphorus. We tested this hypothesis by measuring the excretion rates of nitrogen and phosphorus of Physella acuta, a ubiquitous pulmonate snail that grazes heavily on periphyton, exposed to either copper or

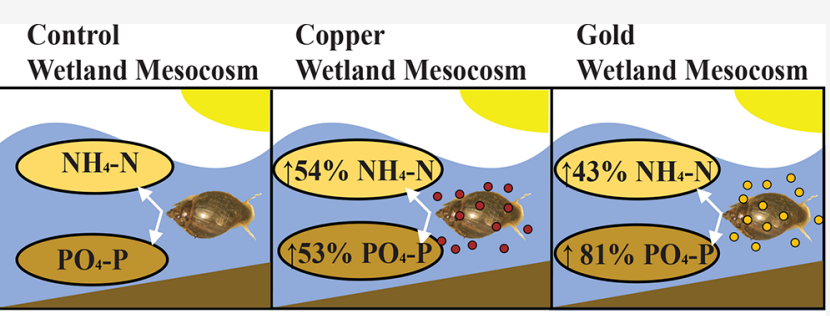

Chronic (6 months) nanoparticle exposure increases snail nutrient excretion rates gold engineered nanoparticles for 6 months in an outdoor wetland mesocosm experiment. Chronic nanoparticle exposure doubled nutrient excretion when compared to the control. Gold nanoparticles increased nitrogen and phosphorus excretion rates more than copper nanoparticles, but overall, both nanoparticles led to higher consumer excretion, despite contrasting particle stability and physiochemical properties. Snails in mesocosms enriched with nitrogen and phosphorus had overall higher excretion rates than ones in ambient (no nutrients added) mesocosms. Stimulation patterns were different between nitrogen and phosphorus excretion, which could have implications for the resulting nutrient ratio in the water column. These results suggest that low concentrations of engineered nanoparticles could alter the metabolism of consumers and increase consumer-mediated nutrient recycling rates, potentially intensifying eutrophication in aquatic systems, for example, the increased persistence of algal blooms as observed in our mesocosm experiment.
\end{abstract}

\section{INTRODUCTION}

Engineered nanoparticles (NPs) are ubiquitous in many commercial products and enter the aquatic environment where they have been shown to have a wide variety of effects. Nanomaterials represent a sizeable fraction of materials used in the global economy and consequently have multiple pathways into the environment. Flow into aquatic ecosystems by runoff and wastewater is estimated to contribute up to 21,000 metric tons of NPs annually. ${ }^{1}$ Once NPs are released into the environment, they interact with a complex aquatic ecosystem. At present, more extensive research has been conducted on NPs in laboratory settings. ${ }^{2,3}$ Less research has been conducted on the ecosystem-level effects of NPs under realistic environmental conditions, such as chronic long-term exposure and NP interactions with food webs, particularly primary producers and consumers. 4

Primary producers (plants and algae) and consumers (grazers) interact extensively with NPs discharged into aquatic ecosystems. This interaction allows for the transfer of NPs from the water column or sediments into aquatic food webs, resulting in possible negative effects on ecosystems. ${ }^{6,7}$
Although most studies have shown relatively benign effects of NPs, some NPs have toxic effects on organisms including algae, cladocerans, snails, and fish. ${ }^{8-10}$ NPs have been shown to alter organism metabolism and bind to ions such as phosphate, limiting essential nutrients from interacting with cells. ${ }^{11-13}$ Changes to organism metabolism-how organisms take up, transform, and expend energy and materials - can lead to indirect effects on the ecosystem. 14,15

Consumers are an integral part of nutrient dynamics in ecosystems and may affect primary productivity by altering the supply and quality of resources such as nutrients, primarily nitrogen and phosphorus. ${ }^{16}$ Consumer-mediated nutrient recycling is an ecological process, which includes the excretion of dissolved nitrogen and phosphorus by an organism into its

Received: April 8, 2020

Revised: June 2, 2020

Accepted: July 16, 2020

Published: July 16, 2020 
surrounding environment over time. It is commonly used for testing the predictions of important ecological frameworks, such as the metabolic theory of ecology or ecological stoichiometry. ${ }^{17}$ Both of these frameworks use principles of physics, chemistry, and biology to link the biology or elemental composition of individual organisms to the ecology of populations, communities, and ecosystems. ${ }^{15,18,19}$

Previous studies measuring consumer-mediated nutrient recycling have contributed considerably to our understanding of interactions among consumers, algae, and nutrients in aquatic ecosystems. ${ }^{20,21}$ Individual consumer species can directly alter ecosystem function through grazing stored forms of organic nutrients which they then excrete in simplified forms at rates comparable to major nutrient sources. These nutrients excreted by consumers are then immediately available for plant, algal, and microbial uptake and drive consumermediated nutrient recycling. ${ }^{16,22-24}$ Further, the processing of food under varying environmental conditions, particularly contrasting background nutrient enrichment regimes, can lead to differential consumer excretion of nutrients into aquatic ecosystems. $^{25}$

Ecological processes have nutrient requirements, and the excess nutrients, specifically nitrogen and phosphorus, may result in altered ecosystem function. Surface waters have become nutrient-enriched, largely because of urban and agricultural practices, leading to widespread eutrophication of freshwater ecosystems. These eutrophic ecosystems have an increased capacity for algal biomass and primary production. ${ }^{26-28}$ The increase in primary productivity exacerbates diel dissolved oxygen fluctuations and contributes to an overall decline in species richness while encouraging proliferation of more pollution-tolerant species. ${ }^{29-31}$

Proliferation of pollution-tolerant species that recycle nitrogen quickly may affect overall biogeochemical cycling through consumer-mediated nutrient recycling pathways. ${ }^{32}$ Pollution-tolerant species, such as the aquatic snail, Physella acuta, have been shown to persist where NPs co-occur with high nutrient loads in wastewater streams and agricultural runoff. ${ }^{33}$ P. acuta is a freshwater pulmonate snail detritivore and herbivore that reproduces quickly, can occur at high densities, and thrives under a wide range of food and cultural conditions. ${ }^{34-37}$ Previous work showed that they accumulate substantial amounts of NPs relative to other primary consumers and are a good model to study uptake of NPs. ${ }^{9,38-46}$

We know very little of the effects of NPs and nutrients on the relationships among consumers and nutrient remineralization through consumer-mediated nutrient recycling, despite growing evidence that metal-based NPs accumulate in snails and that metals have been found to influence the physiology of snails at high concentrations. ${ }^{47,48}$ Investigations of contaminants within the metabolic theory of ecology, ecological stoichiometry, and consumer-mediated nutrient recycling framework provide an understanding of contaminant effects on aquatic food webs while also assessing the potential utility of these established ecological responses to complex mixtures of NPs and nutrient contaminants in freshwater ecosystems.

Here, we studied the interactive effects of NPs and nutrient enrichment on $P$. acuta with a chronic long-term, lowconcentration dosing scheme to provide a better understanding of NP effects on aquatic food webs and of how NPs may indirectly impact aquatic ecosystems by altering consumer metabolism. We investigated how chronic exposures to copper hydroxide-based (CuNP) or gold (AuNPs) (weekly additions) crossed with two levels of nutrient enrichment influenced the nutrient excretion of consumers in outdoor wetland mesocosms over 6 months. We used CuNPs found in a commercially available fungicide at a realistic dose to investigate particle and biotic interactions likely to be occurring in aquatic ecosystems. We chose AuNPs as a model NP that is easy to detect in complex environmental matrices, in part because of its low natural background, enabling us to study the fate of these particles. ${ }^{49} \mathrm{We}$ hypothesized that consumer nitrogen (as $\mathrm{NH}_{4}{ }^{+}-\mathrm{N}$ ) and phosphorus (as $\mathrm{PO}_{4}{ }^{3-}-\mathrm{P}$ ) excretion would be elevated in response to CuNP exposure relative to AuNPs and control treatments. We hypothesized that copper would increase excretion rates of consumers relative to gold because CuNPs have antimicrobial/antifungal properties and previous research demonstrated that the antimicrobial/antifungal agent triclosan increased snail nutrient excretion. ${ }^{32}$ We hypothesized that consumers in the AuNP mesocosms would excrete similarly to the control mesocosms, as previous studies have used AuNPs as inert NP tracers because of their low dissolution rates in abiotic water and interaction with organisms as a particle. ${ }^{50-52}$ Furthermore, we hypothesized that snails at higher background nutrient treatments would excrete at higher rates than ambient nutrient treatments because consumer food sources in these treatments are nutrient-enriched and more available. ${ }^{53}$ In our study, we saw an increased internal eutrophication in the mesocosms exposed to the combination of NPs and nutrient enrichment. ${ }^{5}$ We wanted to investigate ecosystem level changes, which could drive increased eutrophication, other than primary producers. Consumer responses including consumer-mediated nutrient recycling might be one of the key parameters explaining this phenomenon. Consumer metabolic responses to NPs are largely unknown, but consumer metabolic responses to environmental variables have been known to alter ways in which nutrients are processed in consumers, leading to a differential excretion of nutrients to the water column. ${ }^{54,55}$

\section{MATERIALS AND METHODS}

Wetland Mesocosm Experimental Design. This study took place in the Center for the Environmental Implications of NanoTechnology (CEINT) experimental wetland mesocosm facility located in the Duke Forest in Durham County, North Carolina, USA. We employed the same slant-board mesocosm design that has been described previously. ${ }^{56,57}$ Mesocosms were built to dimensions $(3.66 \mathrm{~m} \times 1.22 \mathrm{~m} \times 0.81 \mathrm{~m})$, were filled with sandy-loam soil, and then with $\sim 250 \mathrm{~L}$ of ground water. This design yields an upland zone with minimal inundation, a transitional zone that is periodically inundated with water, and an aquatic zone that is permanently inundated. The detailed mesocosm setup is found in the Supporting Information, section "Mesocosm Setup", and has been previously reported. $5,38,40$ In June 2015, we added the following organisms to the aquatic zone: rooted macrophyte (Egeria densa), aquatic snails ( $P$. acuta and Lymnaea sp.), and eastern mosquito fish (Gambusia holbrooki).

On September 28, 2015, two levels of nutrients (ambient and enriched) were established through weekly additions. The enriched level received $1 \mathrm{~L}$ of mesocosm water supplemented with $88 \mathrm{mg}$ of $\mathrm{N}\left(\right.$ as $\left.\mathrm{KNO}_{3}\right)$ and $35 \mathrm{mg}$ of $\mathrm{P}\left(\right.$ as $\left.\mathrm{KH}_{2} \mathrm{PO}_{4}\right)$ added throughout the entire aquatic zone. 

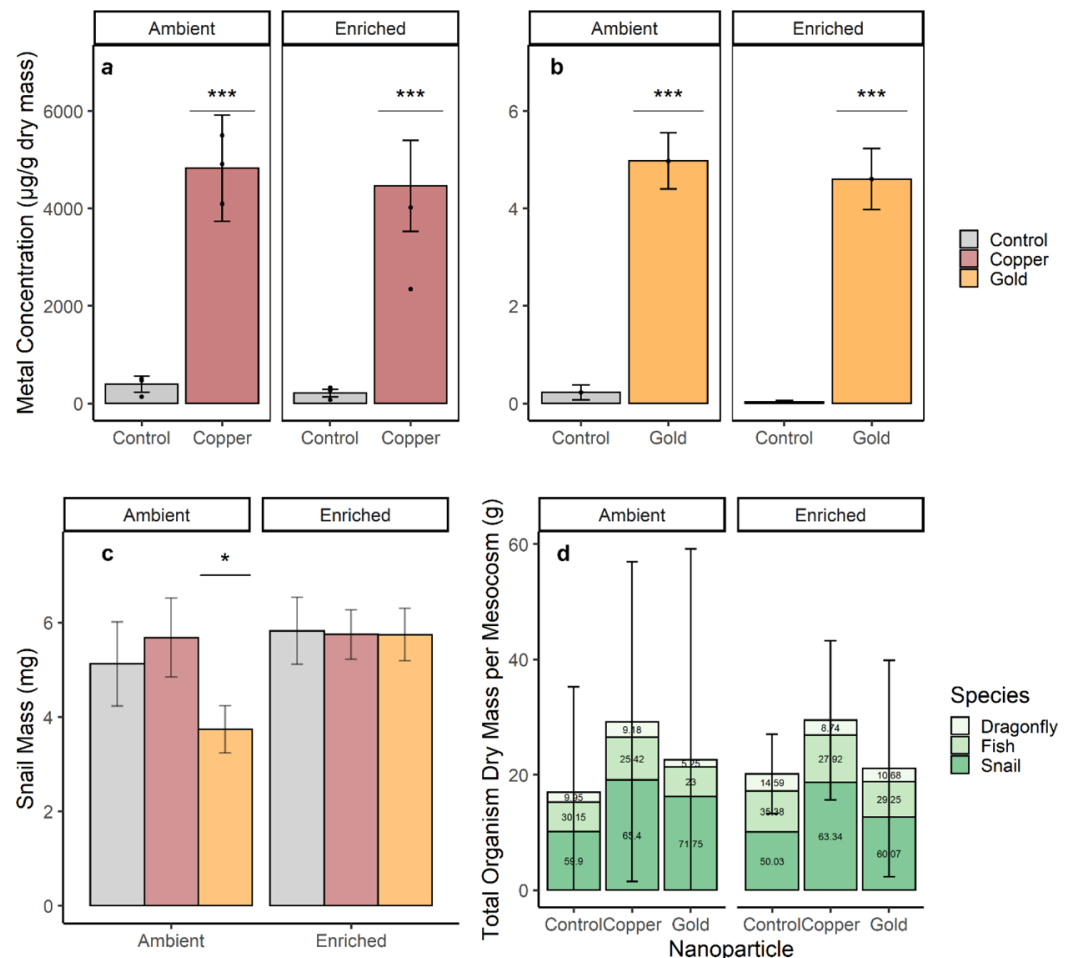

Figure 1. Snail metal concentration $\pm 95 \% \mathrm{CI}$ for $\mathrm{Cu}(\mathrm{a})$ and $\mathrm{Au}(\mathrm{b})$ in snail tissues from NP treatments. Axes and the scale are different for each plot. Black points represent replicate values. NP treatments are distinguished by bar colors. (c) Average DM (mg $\pm 95 \% \mathrm{CI})$ of snails included in excretion experiment per treatment. (d) Average total organismal DM in each mesocosm per treatment $(\mathrm{g} \pm 95 \% \mathrm{CI})$ at the end of the mesocosm experiment.

On January 18, 2016, mesocosms were randomly assigned to NP treatments across the two nutrient treatments to the NP treatments (control, copper, gold). The fully factorial experiment resulted in three treatments with no nutrient additions (ambient): control, CuNP, and AuNP and three treatments with nutrient additions (enriched): control, CuNP, and AuNP. Each treatment was replicated in three independent mesocosms, resulting in a total of 18 mesocosms that were exposed for 192 days (about 6 months). NPs were dosed weekly into mesocosms by mixing freshly sonicated NPs with $1 \mathrm{~L}$ of mesocosm water and distributed throughout the entire aquatic zone. 5,40

The CuNP mesocosms received a weekly dose of $35 \mathrm{mg}$ of Kocide for 6 months, except for the first week of treatment when they received an initial pulse of $374 \mathrm{mg}$ that resulted in a total dose of $0.9816 \mathrm{~g}$ of Kocide per mesocosm over the duration of the study. Kocide contains $27 \% \mathrm{Cu}$ by dry weight, so $358 \mathrm{mg}$ of $\mathrm{Cu}$ from $\mathrm{CuOH}_{2}$ was added to the mesocosms. The concentration of $\mathrm{Cu}$ was intended to be environmentally realistic by simulating field application rates and losses. ${ }^{5}$ This resulted in an average water column $\mathrm{Cu} \pm \mathrm{SE}$ concentration in $\mathrm{CuNP}$ mesocosms of $11 \pm 1.1$ and $13 \pm 2.0 \mu \mathrm{g} / \mathrm{L}$ in the ambient and enriched mesocosms, respectively, over the course of the experiment (Table S1). The mesocosms exposed to AuNPs received a weekly dose of $19 \mathrm{mg} \mathrm{Au}$, resulting in a total dose of $532 \mathrm{mg} \mathrm{Au}$ added over the 6 months of the experiment. $^{5}$ This resulted in an average $\mathrm{Au} \pm \mathrm{SE}$ concentration in the AuNP mesocosms of $6 \pm 1.0$ and $9 \pm$ $1.8 \mu \mathrm{g} / \mathrm{L}$ in the ambient and enriched mesocosms, respectively, over the course of the experiment (Table S1).

Consumer Nutrient Excretion. The nutrient excretion study was conducted during the peak of growing season in July and after snails had been exposed to NPs for 6 months and 3 months prior to the end of the mesocosm experiment. We chose to focus on snails because nutrient excretion is wellstudied in snails, ${ }^{22,32,58-61}$ and snails represented $68 \%$ of the nonplant biomass in our mesocosms. Ten $P$. acuta snails were collected from each control, $\mathrm{Cu}$ and $\mathrm{Au}$ mesocosm and placed into mesocosm-specific plastic bins with mesocosm water. We then placed single snails into $15 \mathrm{~mL}$ conical tubes with $7 \mathrm{~mL}$ of filtered ambient nutrient, control mesocosm water $(0.2 \mu \mathrm{m}$ Nalgene Filter, Thermo Scientific, USA). All snails were incubated at a water temperature of $30{ }^{\circ} \mathrm{C}$ for $95 \pm 0.5 \mathrm{~min}$ (mean $\pm \mathrm{SE})$. After incubation, snails and fecal matter were removed from excretion water. Snails and excretion water were immediately frozen and shipped to Baylor University. Excretion water samples were thawed and filtered $(0.45 \mu \mathrm{m}$ Whatman Filter, Cytiva, USA) to remove any remaining particulates (e.g. feces) prior to analysis. Frozen snails were analyzed for NP uptake by quantifying body burdens of $\mathrm{Cu}$ and $\mathrm{Au}$ using inductively coupled plasma mass spectrometry (ICP-MS). The ICP-MS methods are detailed in the Supporting Information, section "ICP-MS Methods", and were previously described from this mesocosm experiment. ${ }^{38,40}$

$\mathrm{Cu}$ speciation was measured on the dried powder of soft tissues that was kept under a $\mathrm{N}_{2}$ atmosphere. Prior to analysis, the powder was homogenized, pressed into $6 \mathrm{~mm}$ pellets, and sealed with Kapton tape. Pellets were analyzed at the $\mathrm{Cu} \mathrm{K}$ edge $(8.98 \mathrm{keV})$ for X-ray absorption near-edge structure (XANES) spectroscopy under $77 \mathrm{~K}$ cryostat conditions to avoid beam damage. Additional beamline, sample information, and LCF modeling are detailed in the Supporting Information, section "Cu Speciation", and were previously described from this mesocosm experiment. ${ }^{38,40}$ 
Background water nutrient concentrations $\left(\mathrm{NH}_{3}-\mathrm{N}\right.$ and $\mathrm{PO}_{4}-\mathrm{P}$ ) were measured in 25 replicates of filtered, control mesocosm water that was not exposed to snails. Ammonia was determined using the phenolate method and phosphorus was determined using the molybdate colorimetric method and on a Lachat QuikChem 8500 flow-injection autoanalyzer. ${ }^{65,66}$ The snail excretion water was analyzed for $\mathrm{NH}_{3}-\mathrm{N}$ and $\mathrm{PO}_{4}-\mathrm{P}$ in the same manner. The mean background $\mathrm{NH}_{3}-\mathrm{N}$ and $\mathrm{PO}_{4}-\mathrm{P}$ and concentrations were subtracted from the excretion concentrations to determine the snail-excreted $\mathrm{NH}_{3}-\mathrm{N}$ and $\mathrm{PO}_{4}-\mathrm{P} . \mathrm{NH}_{3}-\mathrm{N}$ was measured, but $\mathrm{NH}_{4}-\mathrm{N}$ was estimated using differences in the molecular weight. Hence, we measured ammonia, the predominant form of nitrogen excreted by aquatic mollusks, and reported ammonium, which is the standard practice for measuring nitrogen excretion in aquatic animals. $^{22,32,58,59,62-64}$

Snail and food source (floc, E. densa, periphyton from $E$. densa, and the sediment) were oven-dried at $60{ }^{\circ} \mathrm{C}$, homogenized, and weighed into silver capsules. Capsules were then exposed to $\mathrm{HCl}$ to remove inorganic carbon, ovendried at $60^{\circ} \mathrm{C}$ for $48 \mathrm{~h}$, and wrapped in tin capsules for stable carbon and nitrogen analysis. ${ }^{67}$ Analysis was conducted on a Thermo-Electron Delta V Advantage isotope ratio mass spectrometer (IRMS) with a dual inlet system.

Statistical Analysis. Snail excretion rate $\left(\mathrm{NH}_{4}-\mathrm{N}\right.$ and $\left.\mathrm{PO}_{4}-\mathrm{P} \mu \mathrm{g} / \mathrm{h}\right)$ and metal accumulation in snail tissues $(\mathrm{Cu}$ and $\mathrm{Au} \mu \mathrm{g} / \mathrm{g} \mathrm{DM})$ were modeled using linear mixed models (LMMs) to determine the effects of the NP exposure, nutrient status, snail biomass, and their interaction on both nutrient excretion and bioaccumulation. ${ }^{68}$ The main effects were NP treatment (control, $\mathrm{Au}, \mathrm{Cu}$ ), and nutrient treatment (ambient and enriched), whereas dry mass (DM, mg) was modeled as a covariate because excretion rate was expected to be dependent on snail body mass. ${ }^{63,69}$ Mesocosm number $(n=18)$ was a random effect, which nested individual snail measurements within mesocosms and subsequently modeled the random effect of each mesocosm on these values. ${ }^{68}$ The models were fit using the lmer function of the lme4 package in $\mathrm{R}^{70,71}$ Model fits were evaluated using residual plots, which demonstrated that the model fit the data and met the assumptions of a LMM. Conditional $R^{2}$ values were calculated for the selected model. ${ }^{72}$ Significance of main effects and interactions were estimated using the analysis of variance (ANOVA) function in the car package (Table S2) ${ }^{68,73}$ The function predict.se.MERmod in the lme4 package was used to predict $\mathrm{NH}_{4}-\mathrm{N}$ or $\mathrm{PO}_{4}{ }^{-}-\mathrm{P}$ excretion rates using the model and different combinations of levels of significant main effects or interactions $(p<0.05)$. The fitted models were used to graphically illustrate the predicted mean and $95 \%$ confidence interval (CI) excretion rates by snail DM. Results were plotted in ggplot 2 for both $\mathrm{NH}_{4}-\mathrm{N}$ (Figure 3a,b) and $\mathrm{PO}_{4}-\mathrm{P}$ excretion (Figure 4a,b). ${ }^{74}$

Average snail nutrient recycling rates were determined by averaging snail $\mathrm{NH}_{4}-\mathrm{N}$ and $\mathrm{PO}_{4}-\mathrm{P}$ excretion values by treatment (Figures $3 \mathrm{c}, \mathrm{d}$ and $4 \mathrm{c}, \mathrm{d}$ ). Snail biomass was determined by averaging snail DM from the excretion experiment (Figure 1c). The lsmeans package in $\mathrm{R}$ was used on the full excretion models described in Table S2 to look at pairwise differences between nutrient and NP treatments. ${ }^{75}$

Stable isotope analysis, including snail diet composition, was determined using the MixSIAR package in $\mathrm{R}^{76}$ The $\delta^{13} \mathrm{C}$ and $\delta^{15} \mathrm{~N}$ values for the snail tissue and food sources were considered tracers, and the NP was treated as a fixed effect (Figure S2).

\section{RESULTS}

Metal Accumulation in Snails. $\mathrm{Cu}$ and $\mathrm{Au}$ concentrations in NP-exposed snail tissues were more than 10-fold higher than control snails (Figure 1a,b, $p<0.001$ ). Metal concentrations for CuNP-exposed snails averaged $4622 \mu \mathrm{g} \mathrm{Cu} / \mathrm{g}$ snail and $4.78 \mu \mathrm{g} \mathrm{Au} / \mathrm{g}$ snail for AuNP-exposed snails, with $\mathrm{Cu}$ accumulating at 1000 -fold higher concentrations compared to Au. Nutrient status had no effect on metal accumulation in snails (Figure 1a, $p<0.68$ and Figure $1 \mathrm{~b}, p<0.11$ ).

Average snail body DM ranged from 3.73 to $5.82 \mathrm{mg}$ in the ambient AuNP mesocosms and the enriched control mesocosms, respectively. While both types of NPs accumulated in the snail tissue, CuNPs did not influence the body size of snails either in the ambient or enriched mesocosms (Figure $1 c, p<0.34$ and $p<0.99)$. Chronic AuNP exposure in the ambient mesocosms led to a reduction of snail body DM (Figure 1c, $p<0.05$ ), but there was no difference in DM between the enriched AuNP snails and the enriched control snails (Figure 1c, $p<0.99$ ). Without chronic NP dosing, there was no difference in snail body size between nutrient treatments (Figure 1c, $p<0.08$ ). Snails represented $68 \%$ of the nonplant, living organism biomass, and $P$. acuta represented $83 \%$ of the snail biomass (Figure 1d).

Measurements of $\mathrm{Cu}$ speciation in the snail tissue (Figure 2) indicate that the $\mathrm{Cu}$ uptake was predominately of an ionic form

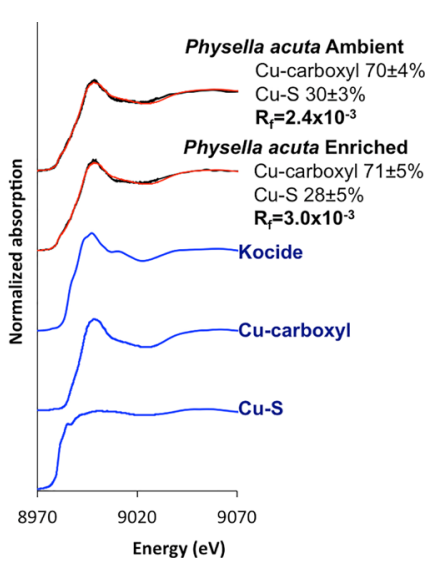

Figure 2. XANES at $\mathrm{Cu}$ K-edge for $P$. acuta sampled in either ambient or enriched mesocosms in comparison with Kocide, $\mathrm{Cu}-$ carboxyl, and $\mathrm{Cu}-\mathrm{S}$ references, as described in (Avellan et al., 2020). ${ }^{40}$ Results of the linear combination analysis (LCA) of the P. acuta spectra are also presented along with their quality factor $\left(R_{\mathrm{f}}\right)$ as detailed in the Methods section. More details of $\mathrm{Cu}$ speciation can be found in the Supporting Information, and the references used as potential additional compounds for the LCA can be found in Figure S1.

bound to carboxyl groups $(\sim 70 \%)$, with the remainder represented by sulfidized $\mathrm{Cu}(\sim 30 \%)$. Kocide CuNPs are primarily $\mathrm{Cu}(\mathrm{OH})_{2}$, yet there was no contribution of $\mathrm{Cu}(\mathrm{OH})_{2}$ in the XANES spectra, suggesting that snails are not taking up the CuNPs directly through grazing. The addition of nutrients in the system did not change the speciation of copper associated with the snails. Tissue concentrations were too low to measure $\mathrm{Au}$ speciation in snails.

Nitrogen Excretion. Nitrogen excretion rates increased linearly as snail DM (covariate) increased across all NP and nutrient mesocosms (Figure 3a,b). NPs had the largest effect on $\mathrm{N}$ excretion, but nutrient and the interaction between DM 

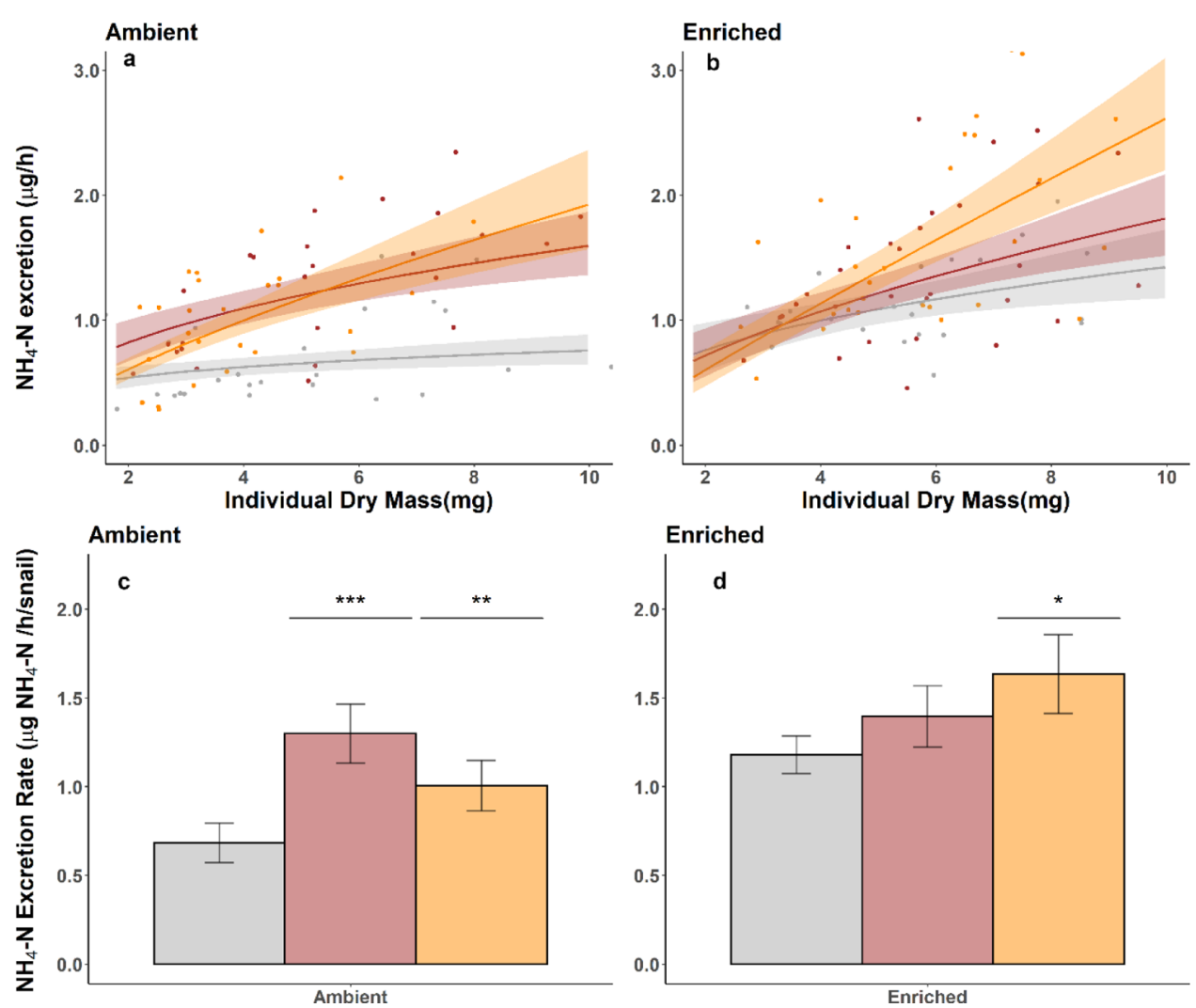

Figure 3. Nitrogen excretion rates expressed by individual snail body DM (mg) in the (a) ambient and (b) enriched mesocosms. NPs are distinguished by shading color. Lines and shaded areas represent predicted means and $95 \%$ CIs from LMM. Mean nitrogen excretion rates by $P$. acuta after NP exposure in the (c) ambient and (d) enriched mesocosms. Means and $95 \%$ CIs are presented, and significant differences $(* * * p<$ $0.001, * * p<0.01, * p<0.05)$ are indicated by asterisks.

and NPs also had significant effects (Table S2, $p<0.001, p<$ $0.05)$. The conditional $R^{2}$ value for the nitrogen excretion LMM is 0.57 , which describes the proportion of variance explained by the fixed and random factors (Table S2). Although $\mathrm{N}$ excretion rates were similar for snails with low $\mathrm{DM}$ in all treatments, as $\mathrm{DM}$ increased, $\mathrm{N}$ excretion rates in AuNP-exposed snails had larger slopes than those observed for CuNP-exposed snails. Both AuNP and CuNP-exposed snails had larger slopes than those observed for control snails.

In ambient mesocosms, the amount of $\mathrm{N}$ excreted per mean individual snail was 90 and $47 \%$ higher in the CuNPs and AuNPs mesocosms, respectively, compared to the ambient control mesocosms (Figure $3 c, p<0.001, p<0.01$ ). However, in enriched mesocosms, the amount of $\mathrm{N}$ excreted per average individual snail was $38 \%$ higher in the AuNP mesocosms (Figure 3d, $p<0.05$ ). Snails from the enriched-CuNP mesocosms experienced an $18 \%$ increase in $\mathrm{N}$ excretion, but this increase was not statistically different from the enriched control mesocosms. After accounting for the effect of NPs, snails from the enriched mesocosms excreted $72 \%$ more $\mathrm{N}$ than snails from the ambient mesocosms (Figure 3c,d, $p<$ $0.001)$.

Phosphorus Excretion. There were significant NP and nutrient effects on $\mathrm{P}$ excretion rate, with NPs having a larger influence on snail P excretion than nutrients (Table S2, $p<$ $0.001, p<0.05)$. There was a significant DM and NP interaction, indicating that control, $\mathrm{Au}$, and $\mathrm{Cu} \mathrm{NP}$ mesocosms had different effects on snail $P$ excretion as a function of snail $\mathrm{DM}$ (Table S2, $p<0.05$ ). The conditional $R^{2}$ value for the phosphorus excretion LMM is 0.45 (Table S2). Phosphorus excretion increased significantly with increasing DM in the ambient CuNP mesocosms (Figure 4a). Conversely, ambient and enriched AuNP and enriched CuNP mesocosms showed little change in P excretion with increasing DM (Figure 4a,b). Ambient and enriched control mesocosms had a slightly negative relationship in $\mathrm{P}$ excretion with increasing DM.

$\mathrm{P}$ excretion per mean individual snail was 94 and $110 \%$ higher in the ambient CuNP and AuNP mesocosms, respectively, compared to the ambient control mesocosms (Figure $4 c, p<0.001$ ). The mass of $\mathrm{P}$ excreted per mean individual snail was $52 \%$ higher in the enriched AuNP mesocosms, respectively, compared to the enriched control mesocosms (Figure 4d, $p<0.01$ ). Snails from the enriched CuNP mesocosms had a slight increase in P excretion (11\%), but it was not statistically different from the enriched control mesocosms (Figure $4 \mathrm{~d}, p<0.52$ ). After accounting for the effect of NPs, snails excreted $71 \%$ more $P$ per mean individual in the enriched than in the ambient mesocosms (Figure $4 \mathrm{c}, \mathrm{d}, p$ $<0.001)$.

\section{DISCUSSION}

Consumer-mediated nutrient recycling balances the requirements of organisms for energy and nutrients and the resulting relationship between diet, growth rates, and excretion. ${ }^{17,18,32}$ Through excretion, consumers can be important drivers of nutrient cycling and can supply nutrients at rates comparable to other major nutrient sources in aquatic ecosystems. ${ }^{2,59,69}$ Previous analyses have found the prediction of nutrient excretion for any animal taxon or aquatic ecosystem to be 

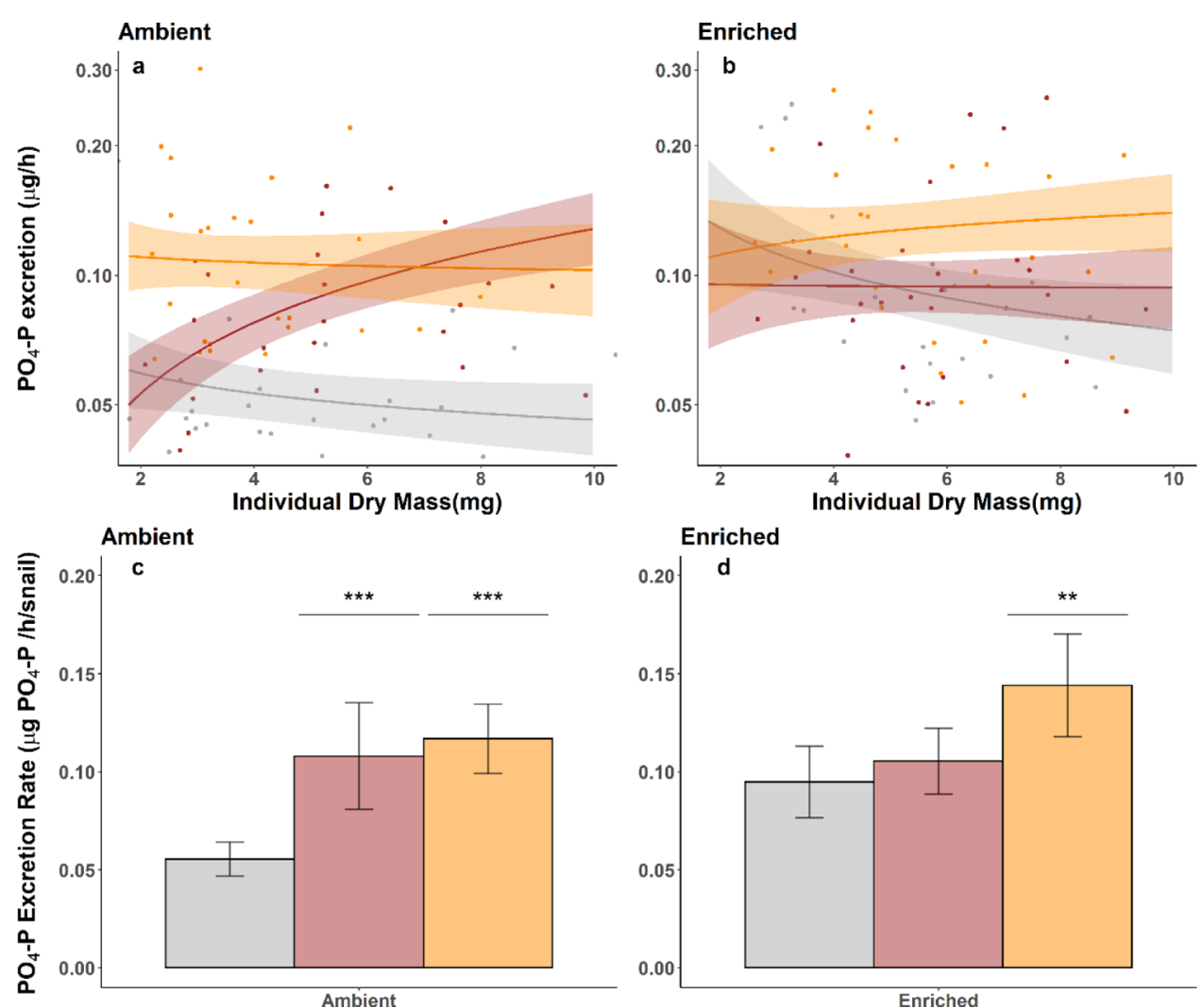

Figure 4. Phosphorus excretion rates expressed by individual snail body DM (mg) in the (a) ambient and (b) enriched mesocosms. NPs are distinguished by shading color. Lines and shaded areas represent predicted means and 95\% CIs from LMMs. Mean phosphorus excretion rate of $P$. acuta after NP exposure in the (c) ambient and (d) enriched mesocosms. Means and $95 \%$ confidence intervals are presented and significant differences $(* * * p<0.001, * * p<0.01, * p<0.05)$ are indicated by asterisks.

best described using body size, water temperature, trophic guild, and vertebrate classification. ${ }^{17}$

Here, we see that $\mathrm{N}$ and $\mathrm{P}$ excretion rates of consumers increased as much as two-fold in response to chronic NP exposure in both ambient and enriched mesocosms between snails of the same species, sizes, and at the same water temperature. The best predictors of aquatic organism excretion were all equivalent in our study, yet we see a doubling of $\mathrm{N}$ and $\mathrm{P}$ excretion, strongly indicating that NP exposure is the driving variable behind this increased excretion. This two-fold change in cycling of nutrients by consumers means that algal communities have nutrients available to them at twice the rate when consumers are exposed to chronic NPs. Thus, NP exposure to consumers may result in increased primary production rates, and in our system, it resulted in NP mesocosms spending a larger proportion of time above the nutrient threshold where blooms occur. ${ }^{5,32,77,78}$ While body size is typically the primary driver of nutrient excretion, we saw no difference in snail body sizes between treatments, with the exception of smaller snails in the ambient AuNP mesocosms, although we saw a difference in nutrient excretion. Stable isotope analysis of snail food sources and snail body tissue across treatments showed an indistinguishable preference for periphyton, Egeria, and "floc" compared to other food sources (Figure S2). Floc is a matrix of amorphous detritus, periphyton, and animal feces (particularly snails), which is why snail isotopes aligned so closely to the floc-it was likely the signature of their own waste product rather than their dominant food, which was periphyton. This indicates that there is likely a disparity in how snails are compensating for excreted phosphorus under NP treatments, whether it be compensatory feeding, increased energy demands to maintain homeostasis, increased $\mathrm{P}$ associated with fecal matter, or another mechanism to be determined in future work. ${ }^{60,79}$

Particle dissolution rate is important because it determines if the organism interacts with a dissolved or a particulate metal in aquatic ecosystems. Although both NPs experienced some dissolution in different compartments of the mesocosms, CuNPs dissolve more rapidly in the water column than AuNPs. ${ }^{40}$ Measurements during this experiment indicate that CuNPs rapidly dissolve $\left(t_{1 / 2}=33 \mathrm{~h}\right.$ in our mesocosms), releasing $\mathrm{Cu}$ ions that form a complex with organic matter and sediment onto $E$. densa and the floc. ${ }^{40,80}$ The surface of $E$. densa and the floc is where the snails have high grazing activity and encounter the complexed ionic $\mathrm{Cu}$ and some $\mathrm{CuS}$ species (Figures 2 and S2). While AuNPs have low dissolution rates in abiotic water and generally interact with organisms as particles, this was not true in our mesocosms containing E. densa. ${ }^{50-52}$ The dosed AuNPs in the mesocosms associated with E. densa were transformed into oxidized species by periphyton. ${ }^{81}$ At the time of the snail excretion study, most of the added AuNPs were associated with the E. densa periphyton and the floc, the primary grazing areas for the snails. All of the Au associated with $E$. densa and $\sim 10 \%$ of the $\mathrm{Au}$ in the floc had dissolved and become associated with new ligands. ${ }^{40}$ Therefore, snails were likely to be feeding on a combination of ionic Au species and AuNPs. While accumulation into the consumer tissue type varied by the NP type and differences in their rates of dissolution in the water column, consumer excretion rates in the mesocosms exposed to NPs are similar. This may be 
because snails primarily uptake dissolved and complexed forms of the metals and not pristine NPs. ${ }^{82,83}$

Snails accumulated high amounts of metals in their soft tissues after 6 months of exposure, especially for CuNPs (4622 $\mu \mathrm{g} / \mathrm{g}) . \mathrm{Cu}$ speciation in the snail tissue was mainly associated with carboxyl groups (Figure 2). Copper is a biologically relevant element to consumers; it is actively and intentionally taken up and tightly regulated by organisms. It has direct interactions with amino acid and carboxyl side chains within peptide chains and is critical to organismal biochemical reactions. ${ }^{84}$ Conversely, gold is not a biologically relevant metal in consumers. Organisms in aquatic ecosystems are unlikely to encounter gold NPs or complexed Au ions, and therefore, it is a novel contaminant. ${ }^{85}$ This could explain the lower amount of $\mathrm{Au}$ in snail tissues compared to $\mathrm{Cu}$. However, these differences may also be the result of the faster dissolution rate of CuNPs in the water column and the resulting differences in their distribution in the mesocosms. ${ }^{40}$ While NP body burdens were studied, they did not correlate well with consumer excretion. In future work, we intend to investigate possible mechanisms for the increase in nutrient excretion.

While we understand that nutrient recycling increases with NP exposure, we do not know the mechanism(s) behind these alterations. Previous studies have reported an increase in consumer nutrient excretion after exposure to other contaminants, including triclosan. ${ }^{32}$ Triclosan is a well-known antimicrobial and has a probabilistic mechanism to alter the gut microbiome within the consumer. In our study, CuNPs have known antimicrobial properties and, while not typically thought of as an antimicrobial, AuNPs have some effect on microbial communities. ${ }^{81}$ While we could not confirm the direct uptake of AuNPs, some of the $\mathrm{Au}$ in snails is likely AuNPs because the floc contained primarily AuNPs. ${ }^{40}$ In our study, both NPs likely exhibited some antimicrobial properties. ${ }^{81,86-89}$ These properties could alter the gut microbiome in snails and alter food assimilation efficiency. ${ }^{90-92}$ However, most $\mathrm{Cu}$ (and perhaps $\mathrm{Au}$ ) accumulated by snails was as dissolved species. Both ionic $\mathrm{Cu}$ and $\mathrm{Au}$ have demonstrated toxicity in aquatic organisms and may exhibit differential toxicity to snails. ${ }^{48,88,93}$ Another mechanistic explanation is that metal exposure may result in increased energy demands because of metal transport and sequestration, limiting the amount of energy available for nutrient uptake processes. This could be analyzed via metabolite biomarkers and gene expression. ${ }^{2,94,95}$ While NPs are novel additions to consumer environments, nutrient enrichment has been well-studied and identified as a water quality issue worldwide.

Previous studies have found that nutrient enrichment increases consumer excretion and these studies concur with our results. Nutrient enrichment increases consumer excretion because consumers are not sequestering nutrients, as there is a surplus in their food. ${ }^{96}$ Independent of NP exposure, N and $\mathrm{P}$ excretion rates increased by $70 \%$ in the enriched mesocosms compared to ambient mesocosms. This indicates that there is an enriched versus ambient modulated effect. Previous literature has found that organismal excretion increased across agricultural gradients in mayfly species and fish assemblages. ${ }^{97,98}$ The excretion rates that we saw in the control snails in this study were similar to those reported in Physella sp. collected from wetland ecosystems, and our excretion pattern of increasing $\mathrm{N}$ excretion as size increases is consistent with those reported in previous studies. ${ }^{24,59}$ Nutrient enrichment from wastewater streams are frequently mixed with other emerging contaminants, including NPs.

NPs are likely to enter aquatic ecosystems as part of waste streams that include high nutrients (e.g. agricultural fertilizers and wastewaters). This nonlethal impact of NPs on consumers has the potential to exacerbate nutrient pollution and hypoxia in aquatic ecosystems. The doubling of nutrient excretion by consumers could be an overlooked factor in the intensification of eutrophication driven by consumer exposure to contaminants such as NPs. Although our experiment focused on snails, other aquatic consumers interact with NPs and the metal species they transform into through the same exposure pathways. It is likely that this increase in nutrient excretion is applicable to other aquatic consumers who live in similar waste streams with high nutrient loading and contaminant mixtures. In our study, this resulted in an increased frequency of algal blooms in NP mesocosms. ${ }^{5}$ If our experimental mesocosm findings are indicative of global processes, NP and consumer interactions could contribute to widespread increases in aquatic productivity, resulting in more frequent algal blooms and more rapid degradation of aquatic ecosystems.

\section{ASSOCIATED CONTENT}

\section{Supporting Information}

The Supporting Information is available free of charge at https://pubs.acs.org/doi/10.1021/acs.est.0c02197.

Additional information concerning the mesocosm setup, ICP-MS methods, water column metal concentrations, ANOVA results from LMMs, Cu speciation, normalized absorption of XANES spectra of reference compounds, and stable isotope figure (PDF)

\section{AUTHOR INFORMATION}

\section{Corresponding Authors}

Brittany G. Perrotta - Center for the Environmental Implications of NanoTechnology, Duke University, Durham, North Carolina 27708, United States; Center for Reservoir and Aquatic Systems Research (CRASR) and Department of Biology, Baylor University, Waco, Texas 76798, United States; (1) orcid.org/0000-0003-2669-3047;

Email: Brittany_Perrotta@baylor.edu

Ryan S. King - Center for the Environmental Implications of NanoTechnology, Duke University, Durham, North Carolina 27708, United States; Center for Reservoir and Aquatic Systems Research (CRASR) and Department of Biology, Baylor University, Waco, Texas 76798, United States;

Email: Ryan_S_King@baylor.edu

\section{Authors}

Marie Simonin - Center for the Environmental Implications of NanoTechnology and Biology Department, Duke University, Durham, North Carolina 27708, United States; 이이.org/ 0000-0003-1493-881X

Jeffrey A. Back - Center for Reservoir and Aquatic Systems Research (CRASR), Baylor University, Waco, Texas 76798, United States

Steven M. Anderson - Center for the Environmental Implications of NanoTechnology and Biology Department, Duke University, Durham, North Carolina 27708, United States; Department of Forestry \& Environmental Resources, 
North Carolina State University, Raleigh, North Carolina 27695, United States

Astrid Avellan - Center for the Environmental Implications of NanoTechnology, Duke University, Durham, North Carolina 27708, United States; Civil \& Environmental Engineering, Carnegie Mellon University, Pittsburgh, Pennsylvania 15213, United States; 이이. orcid.org/0000-0001-6081-4389

Christina M. Bergemann - Center for the Environmental Implications of NanoTechnology and Biology Department, Duke University, Durham, North Carolina 27708, United States

Benjamin T. Castellon - Center for the Environmental Implications of NanoTechnology, Duke University, Durham, North Carolina 27708, United States; Center for Reservoir and Aquatic Systems Research (CRASR) and Department of Environmental Science, Baylor University, Waco, Texas 76798, United States; 이이. orcid.org/0000-0001-8883-076X

Benjamin P. Colman - Center for the Environmental Implications of NanoTechnology, Duke University, Durham, North Carolina 27708, United States; Department of Ecosystem and Conservation Sciences, University of Montana, Missoula, Montana 59812, United States

Gregory V. Lowry - Center for the Environmental Implications of NanoTechnology, Duke University, Durham, North Carolina 27708, United States; Civil \& Environmental Engineering, Carnegie Mellon University, Pittsburgh, Pennsylvania 15213, United States; orcid.org/0000-0001-8599-008X

Cole W. Matson - Center for the Environmental Implications of NanoTechnology, Duke University, Durham, North Carolina 27708, United States; Center for Reservoir and Aquatic Systems Research (CRASR) and Department of Environmental Science, Baylor University, Waco, Texas 76798, United States; (1) orcid.org/0000-0002-6472-9357

Emily S. Bernhardt - Center for the Environmental Implications of NanoTechnology and Biology Department, Duke University, Durham, North Carolina 27708, United States

Complete contact information is available at: https://pubs.acs.org/10.1021/acs.est.0c02197

\section{Notes}

The authors declare no competing financial interest.

\section{ACKNOWLEDGMENTS}

We thank Ally Adams, Samuel Mahanes, and Jason Rodriguez for their help processing samples. Further, Mark Wiesner, Nicholas Geitner, Heileen Hsu-Kim, and Jason Unrine for their assistance in designing this mesocosm experiment. The authors acknowledge the Baylor University Mass Spectrometry Center and the Baylor University Isotope Laboratory for their support during this work. This material is based upon work supported by the National Science Foundation (NSF) and the Environmental Protection Agency (EPA) under NSF Cooperative Agreement EF0830093 and DBI-1266252, Center for the Environmental Implications of NanoTechnology (CEINT). Any opinions, findings, conclusions, or recommendations expressed in this material are those of the author(s) and do not necessarily reflect the views of the NSF or the EPA. This work has not been subjected to EPA review, and no official endorsement should be inferred. Part of this work used resources of the Advanced Photon Source; a U.S. Department of Energy (DOE) Office of Science User Facility operated for the DOE Office of Science by Argonne National Laboratory under Contract No. DE-AC02-06CH11357. Additional funding was provided by the C. Gus Glasscock, Jr. Endowed Fund for Excellence in Environmental Sciences at Baylor University.

\section{REFERENCES}

(1) Keller, A. A.; McFerran, S.; Lazareva, A.; Suh, S. Global Life Cycle Releases of Engineered Nanomaterials. J. Nanopart. Res. 2013, 15, 1692.

(2) Griffitt, R. J.; Weil, R.; Hyndman, K. A.; Denslow, N. D.; Powers, K.; Taylor, D.; Barber, D. S. Exposure to Copper Nanoparticles Causes Gill Injury and Acute Lethality in Zebrafish (Danio Rerio). Environ. Sci. Technol. 2007, 41, 8178-8186.

(3) Blaise, C.; Gagné, F.; Férard, J. F.; Eullaffroy, P. Ecotoxicity of Selected Nano-Materials to Aquatic Organisms. Environ. Toxicol. 2008, 23, 591-598.

(4) Colman, B. P.; Baker, L. F.; King, R. S.; Matson, C. W.; Unrine, J. M.; Marinakos, S. M.; Gorka, D. E.; Bernhardt, E. S. Dosing, Not the Dose: Comparing Chronic and Pulsed Silver Nanoparticle Exposures. Environ. Sci. Technol. 2018, 52, 10048-10056.

(5) Simonin, M.; Colman, B. P.; Anderson, S. M.; King, R. S.; Ruis, M. T.; Avellan, A.; Bergemann, C. M.; Perrotta, B. G.; Geitner, N. K.; Ho, M.; de la Barrera, B.; Unrine, J. M.; Lowry, G. V.; Richardson, C. J.; Wiesner, M. R.; Bernhardt, E. S. Engineered Nanoparticles Interact with Nutrients to Intensify Eutrophication in a Wetland Ecosystem Experiment. Ecol. Appl. 2018, 28, 1435-1449.

(6) Ferry, J. L.; Craig, P.; Hexel, C.; Sisco, P.; Frey, R.; Pennington, P. L.; Fulton, M. H.; Scott, I. G.; Decho, A. W.; Kashiwada, S.; Murphy, C. J.; Shaw, T. J. Transfer of Gold Nanoparticles from the Water Column to the Estuarine Food Web. Nat. Nanotechnol. 2009, 4, 441-444.

(7) Wright, M. V.; Matson, C. W.; Baker, L. F.; Castellon, B. T.; Watkins, P. S.; King, R. S. Titanium Dioxide Nanoparticle Exposure Reduces Algal Biomass and Alters Algal Assemblage Composition in Wastewater Effluent-Dominated Stream Mesocosms. Sci. Total Environ. 2018, 626, 357-365.

(8) Pang, C.; Selck, H.; Misra, S. K.; Berhanu, D.; Dybowska, A.; Valsami-Jones, E.; Forbes, V. E. Effects of Sediment-Associated Copper to the Deposit-Feeding Snail, Potamopyrgus Antipodarum: A Comparison of $\mathrm{Cu}$ Added in Aqueous Form or as Nano- and Micro$\mathrm{CuO}$ Particles. Aquat. Toxicol. 2012, 106-107, 114-122.

(9) Ramskov, T.; Selck, H.; Banta, G.; Misra, S. K.; Berhanu, D.; Valsami-Jones, E.; Forbes, V. E. Bioaccumulation and Effects of Different-Shaped Copper Oxide Nanoparticles in the Deposit-Feeding Snail Potamopyrgus Antipodarum: Bioaccumulation and Effects of CuO Nanoparticles. Environ. Toxicol. Chem. 2014, 33, 1976-1987.

(10) Ali, D.; Yadav, P. G.; Kumar, S.; Ali, H.; Alarifi, S.; Harrath, A. H. Sensitivity of Freshwater Pulmonate Snail Lymnaea Luteola L., to Silver Nanoparticles. Chemosphere 2014, 104, 134-140.

(11) Cedervall, T.; Hansson, L.-A.; Lard, M.; Frohm, B.; Linse, S. Food Chain Transport of Nanoparticles Affects Behaviour and Fat Metabolism in Fish. PLoS One 2012, 7, No. e32254.

(12) Guo, L.; Von Dem Bussche, A.; Buechner, M.; Yan, A.; Kane, A. B.; Hurt, R. H. Adsorption of Essential Micronutrients by Carbon Nanotubes and the Implications for Nanotoxicity Testing. Small 2008, 4, 721-727.

(13) Schultz, A. G.; Boyle, D.; Chamot, D.; Ong, K. J.; Wilkinson, K. J.; McGeer, J. C.; Sunahara, G.; Goss, G. G. Aquatic Toxicity of Manufactured Nanomaterials: Challenges and Recommendations for Future Toxicity Testing. Environ. Chem. 2014, 11, 207-226.

(14) Galic, N.; Sullivan, L. L.; Grimm, V.; Forbes, V. E. When Things Don't Add up: Quantifying Impacts of Multiple Stressors from Individual Metabolism to Ecosystem Processing. Ecol. Lett. 2018, 21, 568-577.

(15) Brown, J. H.; Gillooly, J. F.; Allen, A. P.; Savage, V. M.; West, G. B. Toward a metabolic theory of ecology. Ecology 2004, 85, 17711789. 
(16) Vanni, M. J. Nutrient Transport and Recycling by Consumers in Lake Food Webs: Implications for Algal Communities. In Food Webs: Integration of Patterns \& Dynamics; Polis, G. A., Winemiller, K. O., Eds.; Springer US: Boston, MA, 1996; pp 81-95.

(17) Vanni, M. J.; McIntyre, P. B. Predicting Nutrient Excretion of Aquatic Animals with Metabolic Ecology and Ecological Stoichiometry: A Global Synthesis. Ecology 2016, 97, 3460-3471.

(18) Sterner, R. W.; Elser, J. J. Ecological Stoichiometry; Princeton University Press: Princeton, NJ, 2002.

(19) Allen, A. P.; Gillooly, J. F. Towards an Integration of Ecological Stoichiometry and the Metabolic Theory of Ecology to Better Understand Nutrient Cycling. Ecol. Lett. 2009, 12, 369-384.

(20) Elser, J. J.; Urabe, J. The Stoichiometry of Consumer-Driven Nutrient Recycling: Theory, Observations, and Consequences. Ecology 1999, 80, 735-751.

(21) Hillebrand, H.; Frost, P.; Liess, A. Ecological Stoichiometry of Indirect Grazer Effects on Periphyton Nutrient Content. Oecologia 2008, 155, 619-630.

(22) Hall, R. O.; Tank, J. L.; Dybdahl, M. F. Exotic Snails Dominate Nitrogen and Carbon Cycling in a Highly Productive Stream. Front. Ecol. Environ. 2003, 1, 407-411.

(23) Vanni, M. J.; Flecker, A. S.; Hood, J. M.; Headworth, J. L. Stoichiometry of Nutrient Recycling by Vertebrates in a Tropical Stream: Linking Species Identity and Ecosystem Processes. Ecol. Lett. 2002, 5, 285-293.

(24) Grimm, N. B. Role of Macroinvertebrates in Nitrogen Dynamics of a Desert Stream. Ecology 1988, 69, 1884-1893.

(25) Evans-White, M. A.; Lamberti, G. A. Stoichiometry of Consumer-Driven Nutrient Recycling across Nutrient Regimes in Streams. Ecol. Lett. 2006, 9, 1186-1197.

(26) Dodds, W.; Smith, V. Nitrogen, Phosphorus, and Eutrophication in Streams. Inland Waters 2016, 6, 155-164.

(27) Carpenter, S. R.; Caraco, N. F.; Correll, D. L.; Howarth, R. W.; Sharpley, A. N.; Smith, V. H. Nonpoint Pollution of Surface Waters with Phosphorus and Nitrogen. Ecol. Appl. 1998, 8, 559-568.

(28) Elser, J. J.; Bracken, M. E. S.; Cleland, E. E.; Gruner, D. S.; Harpole, W. S.; Hillebrand, H.; Ngai, J. T.; Seabloom, E. W.; Shurin, J. B.; Smith, J. E. Global Analysis of Nitrogen and Phosphorus Limitation of Primary Producers in Freshwater, Marine and Terrestrial Ecosystems. Ecol. Lett. 2007, 10, 1135-1142.

(29) Søndergaard, M.; Jensen, J. P.; Jeppesen, E. Role of Sediment and Internal Loading of Phosphorus in Shallow Lakes. Hydrobiologia 2003, 506-509, 135-145.

(30) Hilsenhoff, W. L. An Improved Biotic Index of Organic Stream Pollution. Gt. Lakes Entomol. 1987, 20, 7.

(31) Mouthon, J.; Charvet, S. Compared Sensitivity of Species, Genera and Families of Molluscs to Biodegradable Pollution. Ann. Limnol. 1999, 35, 31-39.

(32) Taylor, J. M.; Back, J. A.; Brooks, B. W.; King, R. S. ConsumerMediated Nutrient Recycling Is Influenced by Interactions between Nutrient Enrichment and the Antimicrobial Agent Triclosan. Freshw. Sci. 2016, 35, 856-872.

(33) King, R. S.; Scoggins, M.; Porras, A. Stream Biodiversity Is Disproportionately Lost to Urbanization When Flow Permanence Declines: Evidence from Southwestern North America. Freshw. Sci. 2016, 35, 340-352.

(34) Sturm, C. F.; Pearce, T. A.; Valdés, Á. The Mollusks: A Guide to Their Study, Collection, and Preservation; Universal-Publishers, 2006.

(35) Cope, N. J.; Winterbourn, M. J. Competitive Interactions between Two Successful Molluscan Invaders of Freshwaters: An Experimental Study. Aquat. Ecol. 2004, 38, 83-91.

(36) Albrecht, C.; Kroll, O.; Moreno Terrazas, E.; Wilke, T. Invasion of Ancient Lake Titicaca by the Globally Invasive Physa Acuta (Gastropoda: Pulmonata: Hygrophila). Biol. Invasions 2009, 11, $1821-1826$

(37) Dillon, R. T.; Wethington, A. R.; Rhett, J. M.; Smith, T. P. Populations of the European Freshwater Pulmonate Physa Acuta Are Not Reproductively Isolated from American Physa Heterostropha or Physa Integra. Invertebr. Biol. 2002, 121, 226-234.
(38) Geitner, N. K.; Cooper, J. L.; Avellan, A.; Castellon, B. T.; Perrotta, B. G.; Bossa, N.; Simonin, M.; Anderson, S. M.; Inoue, S.; Hochella, M. F.; Richardson, C. J.; Bernhardt, E. S.; Lowry, G. V.; Ferguson, P. L.; Matson, C. W.; King, R. S.; Unrine, J. M.; Wiesner, M. R.; Hsu-Kim, H. Size-Based Differential Transport, Uptake, and Mass Distribution of Ceria (CeO2) Nanoparticles in Wetland Mesocosms. Environ. Sci. Technol. 2018, 52, 9768-9776.

(39) Spyra, A.; Cieplok, A.; Strzelec, M.; Babczyńska, A. Freshwater Alien Species Physella Acuta (Draparnaud, 1805) - A Possible Model for Bioaccumulation of Heavy Metals. Ecotoxicol. Environ. Saf. 2019, $185,109703$.

(40) Avellan, A.; Simonin, M.; Anderson, S. M.; Geitner, N. K.; Bossa, N.; Spielman-Sun, E.; Bernhardt, E. S.; Castellon, B. T.; Colman, B. P.; Cooper, J. L.; Ho, M.; Hochella, M. F.; Hsu-Kim, H.; Inoue, S.; King, R. S.; Laughton, S.; Matson, C. W.; Perrotta, B. G.; Richardson, C. J.; Unrine, J. M.; Wiesner, M. R.; Lowry, G. V. Differential Reactivity of Copper- and Gold-Based Nanomaterials Controls Their Seasonal Biogeochemical Cycling and Fate in a Freshwater Wetland Mesocosm. Environ. Sci. Technol. 2020, 54, $1533-1544$

(41) Croteau, M.-N.; Misra, S. K.; Luoma, S. N.; Valsami-Jones, E. Bioaccumulation and Toxicity of $\mathrm{CuO}$ Nanoparticles by a Freshwater Invertebrate after Waterborne and Dietborne Exposures. Environ. Sci. Technol. 2014, 48, 10929-10937.

(42) Croteau, M.-N.; Dybowska, A. D.; Luoma, S. N.; ValsamiJones, E. A Novel Approach Reveals That Zinc Oxide Nanoparticles Are Bioavailable and Toxic after Dietary Exposures. Nanotoxicology 2011, 5, 79-90.

(43) Hoang, T. C.; Rogevich, E. C.; Rand, G. M.; Frakes, R. A. Copper Uptake and Depuration by Juvenile and Adult Florida Apple Snails (Pomacea Paludosa). Ecotoxicology 2008, 17, 605.

(44) Ma, J.; Zhou, C.; Li, Y.; Li, X. Biochemical Responses to the Toxicity of the Biocide Abamectin on the Freshwater Snail Physa Acuta. Ecotoxicol. Environ. Saf. 2014, 101, 31-35.

(45) Ramskov, T.; Croteau, M.-N.; Forbes, V. E.; Selck, H. Biokinetics of Different-Shaped Copper Oxide Nanoparticles in the Freshwater Gastropod, Potamopyrgus Antipodarum. Aquat. Toxicol. 2015, 163, 71-80.

(46) Gonçalves, S. F.; Pavlaki, M. D.; Lopes, R.; Hammes, J.; Gallego-Urrea, J. A.; Hassellöv, M.; Jurkschat, K.; Crossley, A.; Loureiro, S. Effects of Silver Nanoparticles on the Freshwater Snail Physa Acuta: The Role of Test Media and Snails' Life Cycle Stage. Environ. Toxicol. Chem. 2017, 36, 243-253.

(47) Bernot, R. J.; Kennedy, E. E.; Lamberti, G. A. Effects of Ionic Liquids on the Survival, Movement, and Feeding Behavior of the Freshwater Snail, Physa Acuta. Environ. Toxicol. Chem. 2005, 24, 1759-1765.

(48) Brix, K. V.; Esbaugh, A. J.; Grosell, M. The Toxicity and Physiological Effects of Copper on the Freshwater Pulmonate Snail, Lymnaea Stagnalis. Comp. Biochem. Physiol., Part C: Toxicol. Pharmacol. 2011, 154, 261-267.

(49) Mahapatra, I.; Sun, T. Y.; Clark, J. R. A.; Dobson, P. J.; Hungerbuehler, K.; Owen, R.; Nowack, B.; Lead, J. Probabilistic Modelling of Prospective Environmental Concentrations of Gold Nanoparticles from Medical Applications as a Basis for Risk Assessment. J. Nanobiotechnol. 2015, 13, 93.

(50) Glenn, J. B.; Klaine, S. J. Abiotic and Biotic Factors That Influence the Bioavailability of Gold Nanoparticles to Aquatic Macrophytes. Environ. Sci. Technol. 2013, 47, 10223-10230.

(51) García-Cambero, J. P.; Núñez García, M.; López, G. D.; Herranz, A. L.; Cuevas, L.; Pérez-Pastrana, E.; Cuadal, J. S.; Castelltort, M. R.; Calvo, A. C. Converging Hazard Assessment of Gold Nanoparticles to Aquatic Organisms. Chemosphere 2013, 93, 1194-1200.

(52) Hull, M. S.; Chaurand, P.; Rose, J.; Auffan, M.; Bottero, J.-Y.; Jones, J. C.; Schultz, I. R.; Vikesland, P. J. Filter-Feeding Bivalves Store and Biodeposit Colloidally Stable Gold Nanoparticles. Environ. Sci. Technol. 2011, 45, 6592-6599. 
(53) Cross, W. F.; Benstead, J. P.; Rosemond, A. D.; Bruce Wallace, J. Consumer-Resource Stoichiometry in Detritus-Based Streams. Ecol. Lett. 2003, 6, 721-732.

(54) Devine, J. A.; Vanni, M. J. Spatial and Seasonal Variation in Nutrient Excretion by Benthic Invertebrates in a Eutrophic Reservoir. Freshw. Biol. 2002, 47, 1107-1121.

(55) Ikeda, T. Metabolic Rates of Epipelagic Marine Zooplankton as a Function of Body Mass and Temperature. Mar. Biol. 1985, 85, 111.

(56) Lowry, G. V.; Gregory, K. B.; Apte, S. C.; Lead, J. R. Transformations of Nanomaterials in the Environment. Environ. Sci. Technol. 2012, 46, 6893-6899.

(57) Colman, B. P.; Espinasse, B.; Richardson, C. J.; Matson, C. W.; Lowry, G. V.; Hunt, D. E.; Wiesner, M. R.; Bernhardt, E. S. Emerging Contaminant or an Old Toxin in Disguise? Silver Nanoparticle Impacts on Ecosystems. Environ. Sci. Technol. 2014, 48, 5229-5236. (58) Moslemi, J. M.; Snider, S. B.; MacNeill, K.; Gilliam, J. F.; Flecker, A. S. Impacts of an Invasive Snail (Tarebia Granifera) on Nutrient Cycling in Tropical Streams: The Role of Riparian Deforestation in Trinidad, West Indies. PloS One 2012, 7, No. e38806.

(59) Vanni, M. J.; McIntyre, P. B.; Allen, D.; Arnott, D. L.; Benstead, J. P.; Berg, D. J.; Brabrand, AÅ.; Brosse, S.; Bukaveckas, P. A.; Caliman, A.; Capps, K. A.; Carneiro, L. S.; Chadwick, N. E.; Christian, A. D.; Clarke, A.; Conroy, J. D.; Cross, W. F.; Culver, D. A.; Dalton, C. M.; Devine, J. A.; Domine, L. M.; Evans-White, M. A.; Faafeng, B. A.; Flecker, A. S.; Gido, K. B.; Godinot, C.; Guariento, R. D.; HaertelBorer, S.; Hall, R. O.; Henry, R.; Herwig, B. R.; Hicks, B. J.; Higgins, K. A.; Hood, J. M.; Hopton, M. E.; Ikeda, T.; James, W. F.; Jansen, H. M.; Johnson, C. R.; Koch, B. J.; Lamberti, G. A.; Lessard-Pilon, S.; Maerz, J. C.; Mather, M. E.; McManamay, R. A.; Milanovich, J. R.; Morgan, D. K. J.; Moslemi, J. M.; Naddafi, R.; Nilssen, J. P.; Pagano, M.; Pilati, A.; Post, D. M.; Roopin, M.; Rugenski, A. T.; Schaus, M. H.; Shostell, J.; Small, G. E.; Solomon, C. T.; Sterrett, S. C.; Strand, Ø.; Tarvainen, M.; Taylor, J. M.; Torres-Gerald, L. E.; Turner, C. B.; Urabe, J.; Uye, S.-I.; Ventelä, A.-M.; Villeger, S.; Whiles, M. R.; Wilhelm, F. M.; Wilson, H. F.; Xenopoulos, M. A.; Zimmer, K. D. A Global Database of Nitrogen and Phosphorus Excretion Rates of Aquatic Animals. Ecology 2017, 98, 1475.

(60) Liess, A.; Haglund, A.-L. Periphyton Responds Differentially to Nutrients Recycled in Dissolved or Faecal Pellet Form by the Snail Grazer Theodoxus Fluviatilis. Freshw. Biol. 2007, 52, 1997-2008.

(61) Hill, W. R.; Griffiths, N. A. Nitrogen Processing by Grazers in a Headwater Stream: Riparian Connections. Freshw. Biol. 2017, 62, 1729.

(62) Campbell, J. W.; Bishop, S. H. Nitrogen Metabolism in Molluscs.Comparative Biochemistry of Nitrogen Metabolism. I: The Invertebrates; Academic Press, 1970; pp 103-206.

(63) Hall, R. O. J.; Koch, B. J.; Marshall, M. C.; Taylor, B. W.; Tronstad, L. M. How Body Size Mediates the Role of Animals in Nutrient Cycling in Aquatic Ecosystems. In Body Size: The Structure and Function of Aquatic Ecosystems; Hildrew, A. G., Raffaelli, D. G., Edmonds-Brown, R., Eds.; Cambridge University Press: Cambridge, 2007; pp 286-305.

(64) Evans-White, M. A.; Lamberti, G. A. Grazer Species Effects on Epilithon Nutrient Composition. Freshw. Biol. 2005, 50, 1853-1863.

(65) U.S. EPA. Determination of Phosphorus by Semi-Automated Colorimetry; Method 365.1 Revision 2.0; US EPA: Cincinnati, OH USA, 1993.

(66) U.S. EPA. Determination of Nitrate-Nitrite Nitrogen by Automated Colorimetry; Method 353.2. 1 Revision 2.0; US EPA: Cincinnati, OH USA, 1993.

(67) Jaschinski, S.; Hansen, T.; Sommer, U. Effects of Acidification in Multiple Stable Isotope Analyses. Limnol. Oceanogr. 2008, 6, 1215.

(68) Zuur, A. F.; Ieno, E. N.; Walker, N. J.; Saveliev, A.; Smith, G. M.Mixed Effects Models and Extensions in Ecology; Gail, M. R., Krickberg, K., Samet, J. M., Tsiatis, A., Wong, W., Eds.; Spring Science and Business Media: New York, NY, 2009.
(69) Vanni, M. J. Nutrient Cycling by Animals in Freshwater Ecosystems. Annu. Rev. Ecol. Systemat. 2002, 33, 341-370.

(70) R Core Team. R: A Language and Environment for Statistical Computing; R Foundation for Statistical Computing: Vienna, Austria, 2019.

(71) Bates, D.; Mächler, M.; Bolker, B.; Walker, S. Fitting Linear Mixed-Effects Models Using \{lme4\}. J. Stat. Software 2015, 67, 1-48.

(72) Nakagawa, S.; Schielzeth, H. A General and Simple Method for Obtaining R2 from Generalized Linear Mixed-Effects Models. Ecol. Evol. 2013, 4, 133-142.

(73) Fox, J.; Weisberg, S. An $\{R\}$ Companion to Applied Regression, 3rd ed.; Sage, 2019.

(74) Wickham, H. Ggplot2: Elegant Graphics for Data Analysis; Springer-Verlag: New York, 2016.

(75) Lenth, R. V. Least-Squares Means: The $\{\mathrm{R}\}$ Package $\{$ lsmeans $\}$. J. Stat. Software 2016, 69, 1-33.

(76) Moore, J. W.; Semmens, B. X. Incorporating Uncertainty and Prior Information into Stable Isotope Mixing Models. Ecol. Lett. 2008, 11, 470-480.

(77) King, R. S.; Richardson, C. J.; Urban, D. L.; Romanowicz, E. A. Spatial Dependency of Vegetation Environment Linkages in an Anthropogenically Influenced Wetland Ecosystem. Ecosystems 2004, 7, 75-97.

(78) Singer, G. A.; Battin, T. J. Anthropogenic Subsidies Alter Stream Consumer-Resource Stoichiometry, Biodiversity and Food Chains. Ecol. Appl. 2007, 17, 376-389.

(79) Fink, P.; Von Elert, E. Physiological Responses to Stoichiometric Constraints: Nutrient Limitation and Compensatory Feeding in a Freshwater Snail. Oikos 2006, 115, 484-494.

(80) Vencalek, B. E.; Laughton, S. N.; Spielman-Sun, E.; Rodrigues, S. M.; Unrine, J. M.; Lowry, G. V.; Gregory, K. B. In Situ Measurement of $\mathrm{CuO}$ and $\mathrm{Cu}(\mathrm{OH}) 2$ Nanoparticle Dissolution Rates in Quiescent Freshwater Mesocosms. Environ. Sci. Technol. Lett. 2016, 3, 375-380.

(81) Avellan, A.; Simonin, M.; McGivney, E.; Bossa, N.; SpielmanSun, E.; Rocca, J. D.; Bernhardt, E. S.; Geitner, N. K.; Unrine, J. M.; Wiesner, M. R.; Lowry, G. V. Gold Nanoparticle Biodissolution by a Freshwater Macrophyte and Its Associated Microbiome. Nat. Nanotechnol. 2018, 13, 1072-1077.

(82) Botha, T. L.; James, T. E.; Wepener, V. Comparative Aquatic Toxicity of Gold Nanoparticles and Ionic Gold Using a Species Sensitivity Distribution Approach. J. Nanomater. 2015, 2015, 1-16.

(83) Jo, M.-R.; Bae, S.-H.; Go, M.-R.; Kim, H.-J.; Hwang, Y.-G.; Choi, S.-J. Toxicity and Biokinetics of Colloidal Gold Nanoparticles. Nanomaterials 2015, 5, 835-850.

(84) Festa, R. A.; Thiele, D. J. Copper: An Essential Metal in Biology. Curr. Biol. 2011, 21, R877.

(85) Southam, G.; Lengke, M. F.; Fairbrother, L.; Reith, F. The Biogeochemistry of Gold. Elements 2009, 5, 303-307.

(86) Reese, A. T.; Pereira, F. C.; Schintlmeister, A.; Berry, D.; Wagner, M.; Hale, L. P.; Wu, A.; Jiang, S.; Durand, H. K.; Zhou, X.; Premont, R. T.; Diehl, A. M.; O'Connell, T. M.; Alberts, S. C.; Kartzinel, T. R.; Pringle, R. M.; Dunn, R. R.; Wright, J. P.; David, L. A. Microbial Nitrogen Limitation in the Mammalian Large Intestine. Nat. Microbiol. 2018, 3, 1441.

(87) Holmes, A. J.; Chew, Y. V.; Colakoglu, F.; Cliff, J. B.; Klaassens, E.; Read, M. N.; Solon-Biet, S. M.; McMahon, A. C.; Cogger, V. C.; Ruohonen, K.; Raubenheimer, D.; Le Couteur, D. G.; Simpson, S. J. Diet-Microbiome Interactions in Health Are Controlled by Intestinal Nitrogen Source Constraints. Cell Metab. 2017, 25, 140-151.

(88) Borase, H. P.; Muley, A. B.; Patil, S. V.; Singhal, R. S. Nano-Eco Toxicity Study of Gold Nanoparticles on Aquatic Organism Moina Macrocopa: As New Versatile Ecotoxicity Testing Model. Environ. Toxicol. Pharmacol. 2019, 68, 4-12.

(89) Elbehiry, A.; Al-Dubaib, M.; Marzouk, E.; Moussa, I. Antibacterial Effects and Resistance Induction of Silver and Gold Nanoparticles against Staphylococcus Aureus-Induced Mastitis and the Potential Toxicity in Rats. MicrobiologyOpen 2019, 8, No. e00698. 
(90) Krajmalnik-Brown, R.; Ilhan, Z. E.; Kang, D. W.; DiBaise, J. K. Effects of Gut Microbes on Nutrient Absorption and Energy Regulation. Nutr. Clin. Pract. 2012, 27, 201-214.

(91) Antunes, L. C. M.; Han, J.; Ferreira, R. B. R.; Lolić, P.; Borchers, C. H.; Finlay, B. B. Effect of Antibiotic Treatment on the Intestinal Metabolome. Antimicrob. Agents Chemother. 2011, 55, 1494-1503.

(92) Schulfer, A.; Blaser, M. J. Risks of Antibiotic Exposures Early in Life on the Developing Microbiome. PLoS Pathog. 2015, 11, No. e1004903.

(93) Balfourier, A.; Luciani, N.; Wang, G.; Lelong, G.; Ersen, O.; Khelfa, A.; Alloyeau, D.; Gazeau, F.; Carn, F. Unexpected Intracellular Biodegradation and Recrystallization of Gold Nanoparticles. Proc. Natl. Acad. Sci. U.S.A. 2020, 117, 103-113.

(94) Williams, K. M.; Gokulan, K.; Cerniglia, C. E.; Khare, S. Size and Dose Dependent Effects of Silver Nanoparticle Exposure on Intestinal Permeability in an in Vitro Model of the Human Gut Epithelium. J. Nanobiotechnol. 2016, 14, 62.

(95) Poynton, H. C.; Lazorchak, J. M.; Impellitteri, C. A.; Blalock, B. J.; Rogers, K.; Allen, H. J.; Loguinov, A.; Heckman, J. L.; Govindasmawy, S. Toxicogenomic Responses of Nanotoxicity in Daphnia Magna Exposed to Silver Nitrate and Coated Silver Nanoparticles. Environ. Sci. Technol. 2012, 46, 6288-6296.

(96) Dalton, C. M.; El-Sabaawi, R. W.; Honeyfield, D. C.; Auer, S. K.; Reznick, D. N.; Flecker, A. S. The Influence of Dietary and WholeBody Nutrient Content on the Excretion of a Vertebrate Consumer. PLoS One 2017, 12, No. e0187931.

(97) Wilson, H. F.; Xenopoulos, M. A. Nutrient recycling by fish in streams along a gradient of agricultural land use. Global Change Biol. 2011, 17, 130-139.

(98) James, L. A. H.; Xenopoulos, M. A.; Wilson, H. F.; Frost, P. C. Land Use Controls Nutrient Excretion by Stream Invertebrates along a Gradient of Agriculture. J. North Am. Benthol. Soc. 2007, 26, 523531. 